\title{
PENGGUNAAN DRONE UNTUK MENDAPATKAN DATA KECELAKAAN LALU LINTAS
}

\author{
Use of Drones to Obtain Traffic Accident Data
}

\author{
Erika Buchari \\ Program Studi S3 Ilmu Teknik Fakultas Teknik \\ Universitas Sriwijaya \\ Jl. Srijaya Negara, Palembang \\ Sumatera Selatan \\ erikabuchari@ft.unsri.ac.id \\ M Taslim Chairuddin \\ Direktorat Lalu Lintas Polda Sumatera Selatan \\ Jl. POM IX, Lorok Pakjo, Kec. Ilir Bar. I \\ Palembang, Sumatera Selatan
}

\author{
Decky Octaviansyah \\ Program Studi S3 Ilmu Teknik Fakultas Teknik \\ Universitas Sriwijaya \\ J1. Srijaya Negara, Palembang \\ Sumatera Selatan \\ decky.dpubm@gmail.com \\ Lisbeth Dolok Saribu \\ Subdit Kamsel Ditlantas Polda Sumatera Selatan \\ Jl. POM IX, Lorok Pakjo, Kec. Ilir Bar. I \\ Palembang, Sumatera Selatan
}

\begin{abstract}
The awareness of using helmet is still far from the expectation. Often, the motorcycle riders and passengers do not use helmet. It is very dangerous for them and other travelers. However, it is not easy to find and analyze the riders that use or do not use helmet, furthermore to get data of the impact of using or not using helmet in the accident. One of the way to get such data is from "Zebra Operation". Nowadays, the development of technology of Aerial Photo and geospatial data can be obtained from small format aerial photo. It can be obtained by the means of Unmanned Aerial Vehicle (UAV) with the attached camera on the UAV so that the geospatial data and motor riders without using helmet can be detected. Rider's behavior can be observed by using UAV or Drone. The aim of this paper is to(1) find the method of observation the travel behavior of riders without using helmet which can endanger other traveler's safety by using drone (2) find the method of finding the location of accident, type and cause of the accident as quick as possible by using drone. Finding of this paper is a reconstruction method of accident, geometric characteristics of the location, type and cause of the accident as quick as possible.
\end{abstract}

Keywords: helmet, motorcycle, drone, accident.

\begin{abstract}
Abstrak
Kesadaran penggunaan helm saat ini masih jauh dari harapan. Seringkali terlihat pengendara sepeda motor dan penumpang yang diboncengnya tidak menggunakan helm. Hal ini sangat membahayakan keselamatannya dan keselamatan banyak orang disekitarnya.Tidak mudah untuk menganalisis jumlah pengguna helm dan pelanggaran lalu lintas, apalagi untuk mengetahui dampak tidak menggunakan helm terhadap korban kecelakaan lalu lintas. Suatu cara termudah untuk mendapatkan data adalah memanfaatkan data dari operasi Zebra. Dengan perkembangan teknologi foto udara, perolehan data permukaan bumi dapat dilakukan dengan menggunakan foto udara format kecil. Foto udara format kecil diperoleh dengan bantuan wahana pesawat udara tanpa awak atau Unmanned Aerial Vehicle dengan meletakkan kamera pada pesawat tersebut sehingga dapat diperoleh data permukaan bumi sesuai dengan yang direncanakan. Perilaku pengendara yang tidak menggunakan helm dan mengabaikan keselamatan diamati dengan menggunakan drone.Tujuan kajian ini adalah untuk:(1) menghasilkan metode pengamatan perilaku pengendara yang tidak menggunakan helm dan yang menyebabkan kecelakaan atau mengabaikan keselamatandengan menggunakan drone,dan (2) menghasilkan metode untuk mendapatkan data kecelakaan, lokasi jenis, dan penyebab kecelakaan secepat mungkin dengan menggunakan drone. Temuan dari paper ini adalah metoda rekonstruksi kecelakaan, karakteristik geometris lokasi, jenis dan penyebab kecelakaan sesegera mungkin.
\end{abstract}

Kata kunci: helm, motor, drone, kecelakaan. 


\section{PENDAHULUAN}

Kesadaran pengendara sepeda motor untuk menggunakan helm belum merata saat ini. Seringkali terlihat pengendara sepeda motor dan penumpang yang diboncengnya tidak menggunakan helm di jalan. Hal ini sangat membahayakan keselamatan pengendara sepeda motor maupun banyak orang disekitarnya.

Buchari dkk (2014) meneliti tentang pentingnya data kecelakaan lalu lintas di Kota Palembang. Banyak informasi dan hubungan variabel yang didapat dari penelitian tersebut, seperti periode yang paling sering terjadi kecelakaan lalu lintas, jenis kendaraan yang bertabrakan, jumlah kecelakaan lalu lintas akibat kerusakan jalan, dan jumlah kecelakaan lalu lintas akibat geometrik jalan yang tidak baik. Selain itu terungkap juga bahwa sekitar $70 \%$ kecelakaan lalu lintas melibatkan sepeda motor dan sudah umum dan lumrah diketahui bahwa sepeda motor dan pengendara sepeda motor tidak berhelm banyak menjadi korban kecelakaan lalu lintas[1].

Penanganan kecelakaan lalu lintas juga tidak mudah. Kadang-kadang polisi dan ambulans yang akan membantu korban kecelakaan lalu lintas susah menerobos kerumunan orang yang melihat dan susah menerobos antrean kendaraan yang tidak berada pada lajurnya, sehingga dibutuhkan waktu yang lama untuk menerobos kerumunan orang dan kendaraan serta membawa korban keluar dari tempat lokasi kecelakaan lalu lintas.

Dengan perkembangan teknologi foto udara, data permukaan bumi dapat diperoleh dengan mudah dengan menggunakan foto udara format kecil. Foto udara format kecil tersebut dapat diperoleh dengan bantuan suatu wahana, berupa pesawat udara tanpa awak, yang dilengkapi dengan kamera sehingga dapat diperoleh data permukaan bumi sesuai dengan yang diinginkan.

Dengan tersedianya teknologi foto udara modern, perlu diperbanyak penelitian-penelitian terkait kecelakaan lalu lintas yang memanfaatkan teknologi pesawat udara tanpa awak atau Unmanned Aerial Vehicle(UAV), yang dikenal dengan sebutan populer "drone" dan dilengkapi dengan peralatan, seperti kamera, sensor, dan GPS. Bruin et al, 2015, sudah melakukan penelitian tentang Drone-Based Traffic Flow Estimation And Tracking Using Computer Vision. Papernya focus terutama kepada arus tak terganggu dalam freeways and national highways. Tujuan utamanya adalah untuk membuat seflexible mungkin untuk memaksimalkan kapasitas dari teknik estimasi dengan kamera yg diletakkan tinggi (polemounted traffic camera footage) dan kamera yang dipasang dalam drone (UAV's on-board camera) [2].

Selama ini teknologi drone, yang dilengkapi dengan camera dan perangkat lunak rekonstruksi sudah mampu untuk merekonstruksi dan mendokumentasikan kecelakaan lalu lintas dengan perolehan data fotogrametrik dalam beberapa menit saja. Dengan demikian perilaku pengendara sepeda motor yang tidak menggunakan helm dan mengabaikan keselamatan akan dapat diamati dengan mudah. Dengan margin kesalahan yang relatif sangat kecil dan penurunan risiko keselamatan polisi dan pengendara sepeda motor, penggunaan drone ini sangat efektif dan pembukaan jalan kembali setelah kejadian kecelakaan lalu lintas dapat dilakukan dengan cepat.

Namun penggunaan alat drone belum ada yang menjurus ke ilmu geodesi dimana koordinat dan level yang diperoleh dapat dimanfaatkan untuk menggambarkan posisi geometris jalan tempat kecelakaan. Oleh karena itu dilakukan penelitian ini untuk analisis geometris dan pendataan cepat kecelakaan. 
Masalah yang coba diangkat pada penelitian ini dirumuskan sebagai berikut:

1. bagaimana mendapatkan data karakteristik dan perilaku pengendara yang tidak menggunakan helm dan pengendara yang menyebabkan kecelakaan lalu lintas atau mengabaikan keselamatan lalu lintas, dan

2. bagaimana mendapatkan data serta penanganan kecelakaan lalu lintas, lokasi, jenis, dan penyebab kecelakaan lalu lintas secepat mungkin

Sedangkan tujuan dari penelitian ini adalah untuk menjawab masalah yang telah dirumuskan, yaitu:

1. menghasilkan metode pengamatan perilaku pengendara sepeda motor yang tidak menggunakan helm dan yang menyebabkan kecelakaan lalu lintas atau mengabaikan keselamatanlalu lintas dengan menggunakan drone, dan

2. menghasilkan metode untuk mendapatkan data kecelakaan lalu lintas, lokasi, jenis, dan penyebab kecelakaan lalu lintas secepat mungkin dengan menggunakan drone.

Kebaruan penelitian terletak pada metode pengambilan data serta metode presentasi data lokasi kecelakaan lalu lintas. Data lokasi yang diperoleh sudah dilengkapi dengan data geometrik jalan tempat terjadinya kecelakaan. Hasil penelitian ini sangat bermanfaat untuk KORLANTAS POLRI, dengan tersedianya informasi kecelakaan lalu lintas dan perilaku pengendara sepeda motor dengan lebih cepat dan siap dianalisis. Selain itu hasil penelitian ini juga dapat dimanfaatkan oleh pihak-pihak lain, seperti Dinas Bina Marga dan Dinas Perhubungan.

\section{METODOLOGI}

Penelitian ini dilakukan dengan langkah-langkah seperti yang ditunjukkan pada Gambar 1.

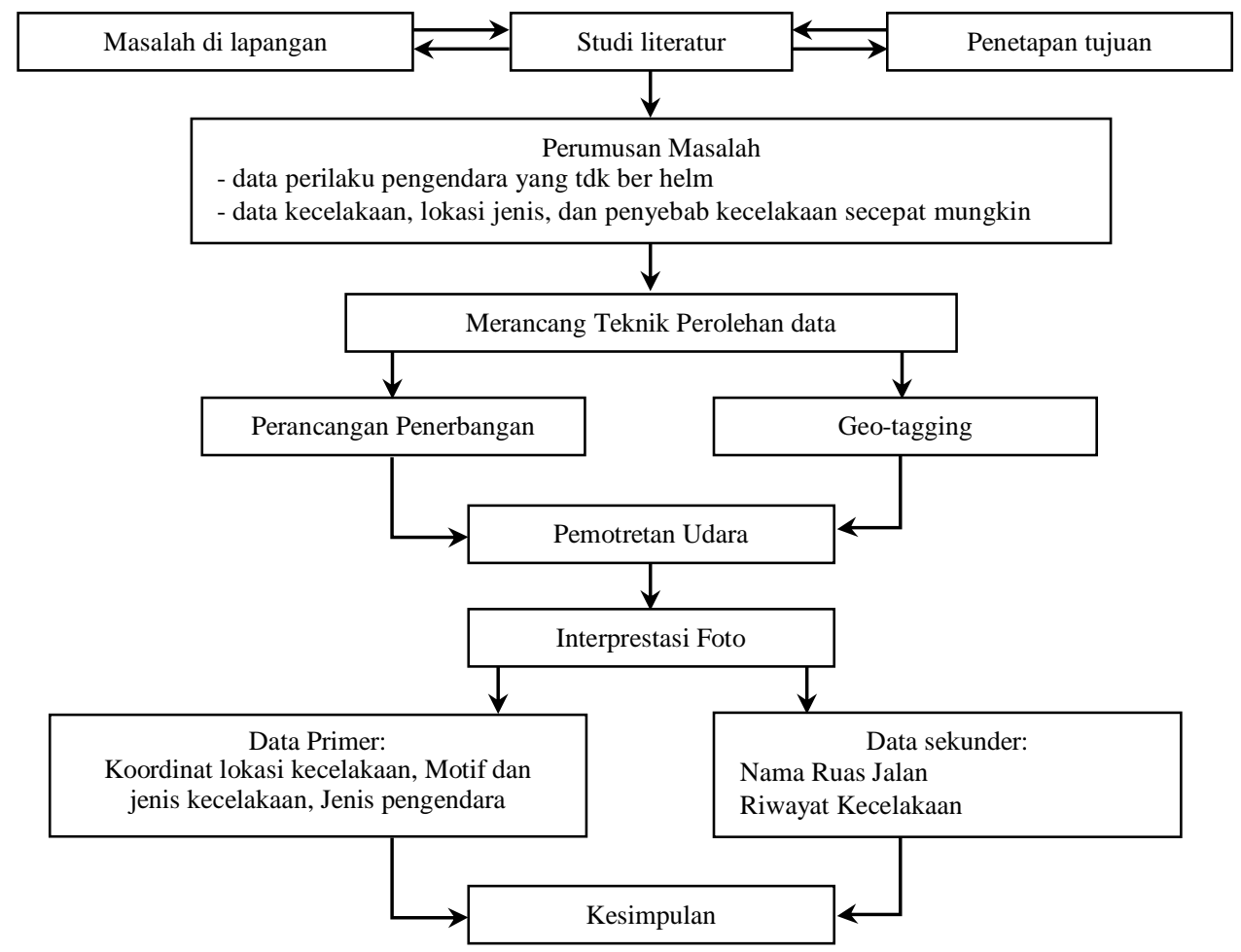

Gambar 1. Bagan alir penelitian 
Untuk pengabilan data dirancang ketinggian pengambilan drone terlebih dahulu. Kamera yang digunakan untuk mendukung pelaksanaan studi ini mempunyai format foto $24 \times 36$ $\mathrm{mm}$ dengan panjang fokus camera (f) $18 \mathrm{~mm}$. Spesifikasi tersebut digunakan untuk mencapai ketinggian dan liputan sebagaimana dirancang untuk memiliki ukuran minimum $1 \mathrm{~cm}$. Ketinggian disesuaikan untuk mendapatkan gambar yang maksimal setelah dilakukan survei pendahuluan di lapangan. Drone dirancang untuk ketinggian yang terlihat pada Gambar 2.

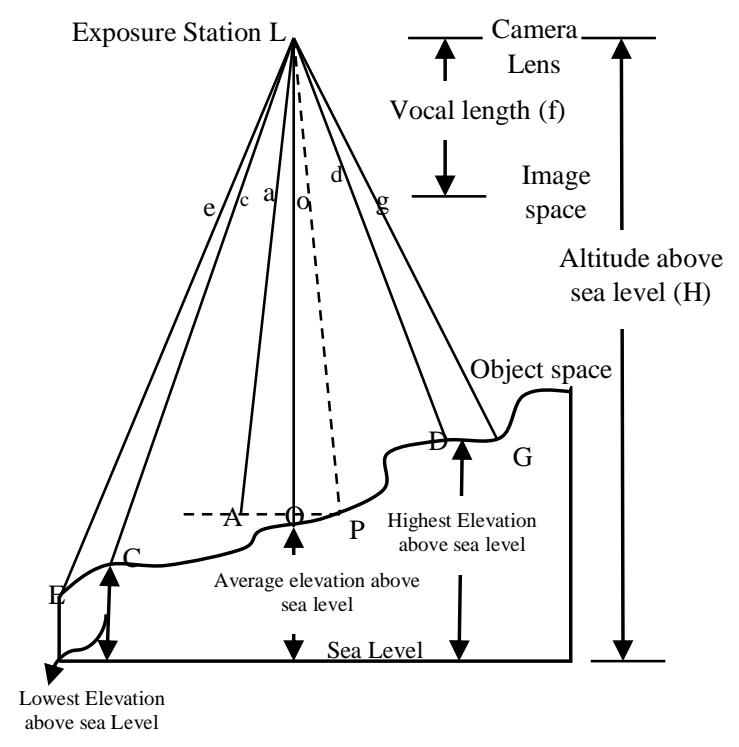

Gambar 2. Rancangan ketinggian terbang drone

\section{HASIL DAN ANALISIS}

Untuk mendapatkan data karakteristik kecelakaan, khususnya tentang pengendara yang menggunakan helm atau tidak ternyata tidak mudah. Data Kecelakaan Lalu Lintas IRSMS digunakan untuk mendapatkan hasil yang diinginkan, yaitu karakteristik pengendara dan kecelakaan. Hasilnya disajikan sebagai berikut.

\section{Hasil Olahan Data Kecelakaan Lalu Lintas IRSMS}

Data olahan yang bersumber dari data mentah IRSMS disajikan dalam bentuk tabel dan tabulasi silang (matriks). Untuk mengetahui karakteristik kecelakaan dan hubungannya dengan pengendara sepeda motor, khususnya menggunakan atau tidak menggunakan helm, diperlukan kajian awal terhadap data sekunder, yang berupa Analisis Matriks Alat Keselamatan dengan Tingkat Luka Palembang 2015, 2016, 2017, dan 2018, seperti yang terdapat pada Tabel1. Alat Keselamatan yang digunakan terdiri dari kategori, Tidak Terdefinisi, Tidak Diketahui, Helm SNI, Helm Non-SNI, Sabuk Keselamatan, Kursi anak, Sabuk Keselamatan Tidak Digunakan, Tidak Menggunakan Helm.

Sedangkan tingkat luka terdiri dari kategori Tidak Diketahui, Tidak Terdefinisi, Meninggal Dunia, Luka Berat, Luka Ringan, dan Tidak Ada Luka 
Tabel 1. Analisis matriks alat yang digunakan dengan jenis kecelakaan

\begin{tabular}{|c|c|c|c|c|c|c|c|c|c|c|c|c|c|c|c|c|c|c|c|c|c|c|c|c|c|c|c|c|}
\hline \multirow{2}{*}{$\begin{array}{c}\text { Alat } \\
\text { Keselamatan } \\
\text { Yang } \\
\text { Digunakan }\end{array}$} & \multicolumn{6}{|c|}{ Tingkat Luka 2015} & \multirow{2}{*}{ Total } & \multicolumn{6}{|c|}{ Tingkat luka 2016} & \multirow[t]{2}{*}{ Total } & \multicolumn{6}{|c|}{ Tingkat luka 2017} & \multirow[t]{2}{*}{ Total } & \multicolumn{6}{|c|}{ Tingkat luka 2018} & \multirow[t]{2}{*}{ Total } \\
\hline & 1 & 2 & 3 & 4 & 5 & 6 & & 1 & 2 & 3 & 4 & 5 & 6 & & 1 & 2 & 3 & 4 & 5 & 6 & & 1 & 2 & 3 & 4 & 5 & 6 & \\
\hline 1 & 0 & 0 & 5 & 11 & 13 & 0 & 29 & 2 & 0 & 15 & 20 & 103 & 0 & 140 & 3 & 5 & 18 & 22 & 90 & 0 & 138 & 1 & 1 & 9 & 6 & 63 & 0 & 80 \\
\hline 2 & 0 & 0 & 0 & 0 & 0 & 0 & 0 & 0 & 0 & 0 & 1 & 3 & 0 & 4 & 0 & 0 & 0 & 0 & 0 & 0 & 0 & 0 & 0 & 0 & 2 & 9 & 0 & 11 \\
\hline 3 & 0 & 0 & 0 & 0 & 0 & 0 & 0 & 0 & 0 & 2 & 4 & 3 & 0 & 9 & 0 & 0 & 0 & 0 & 0 & 0 & 0 & 0 & 0 & 0 & 0 & 7 & 0 & 7 \\
\hline 4 & 0 & 0 & 0 & 0 & 0 & 0 & 0 & 0 & 0 & 0 & 0 & 0 & 0 & 0 & 0 & 0 & 0 & 0 & 0 & 0 & 0 & 0 & 0 & 0 & 0 & 0 & 0 & 0 \\
\hline 5 & 0 & 0 & 0 & 0 & 0 & 0 & 0 & 0 & 0 & 0 & 0 & 0 & 0 & 0 & 0 & 0 & 0 & 0 & 0 & 0 & 0 & 0 & 0 & 0 & 0 & 0 & 0 & 0 \\
\hline 6 & 0 & 0 & 0 & 0 & 0 & 0 & 0 & 0 & 0 & 0 & 0 & 0 & 0 & 0 & 0 & 0 & 0 & 0 & 0 & 0 & 0 & 0 & 0 & 0 & 0 & 0 & 0 & 0 \\
\hline 7 & 0 & 0 & 0 & 0 & 0 & 0 & 0 & 0 & 0 & 0 & 0 & 0 & 0 & 0 & 0 & 0 & 0 & 0 & 0 & 0 & 0 & 0 & 0 & 0 & 0 & 1 & 0 & 1 \\
\hline 8 & 0 & 0 & 0 & 0 & 0 & 0 & 0 & 0 & 0 & 0 & 1 & 0 & 0 & 1 & 0 & 0 & 0 & 0 & 0 & 0 & 0 & 0 & 0 & 2 & 1 & 8 & 0 & 11 \\
\hline Total & 0 & 0 & 5 & 11 & 13 & 0 & 29 & 2 & 0 & 17 & 26 & 109 & 0 & 154 & 3 & 5 & 18 & 22 & 90 & 0 & 138 & 1 & 1 & 11 & 9 & 88 & 0 & 110 \\
\hline
\end{tabular}

Keterangan:

\section{Alat Keselamatan Yang Digunakan}

Tidak Terdefinisi

Tidak Diketahui

Helm SNI

Helm Non-SNI

Sabuk Keselamatan

Kursi anak

Sabuk Keselamatan Tidak Digunakan

Tidak Menggunakan Helm

\section{Tingkat Luka Code}

Tidak Diketahui

Tidak Terdefinisi 2

Meninggal Dunia 3

Luka Berat 4

Luka Ringan 5

Tidak Ada Luka 6 
Pada Tabel 1 dapat dilihat bahwa kode 1 atau penggunaan alat keselamatan tidak terdefinisi yang dominan, untuk setiap luka yaitu sebanyak $29(100 \%)$ di tahun 2015,140 (90,90\%) ditahun 2016, 138 (100\%) ditahun 2017, dan 80 (72,73\%) ditahun 2018. Sementara kategori lain tidak ditemukan datanya seperti Helm SNI, Helm Non-SNI, Sabuk Keselamatan, Kursi anak, Sabuk Keselamatan Tidak Digunakan, Tidak Menggunakan Helm. Padahal ini lah yang sedang ingin diketahui.

Harapan ada ketika data menunjukkan bahwa di tahun 2018 pendataan mulai membaik dan mendeteksi adanya akibat tidak menggunakan helm, yaitu yang berakibat meninggal dunia 2 orang $(1,81 \%)$, yang luka berat 1 orang $(0,9 \%)$, dan yang luka ringan 8 orang $(7,27 \%)$.

Inilah yang mendasari kajian selanjutnya untuk menggunakan drone dalam pendataan kecelakaan.

\section{KAJIAN METODE PENGGUNAAN DRONE UNTUK PENDATAAN}

\section{Penentuan Tinggi Terbang}

Identifikasi jalan dan kerusakan jalan memerlukan tingkat kedetailan hingga lebar retak minimal $0,5 \mathrm{~cm}$. Untuk itu dalam melakukan perencanaan penerbangan harus memperhatikan bahwa objek yang bisa dibaca oleh foto mempunyai retak kerusakan jalan minimal $0,5 \mathrm{~cm}$. Untuk memperoleh objek dengan tingkat kedetailan tersebut, tinggi terbang harus ditentukan terlebih dahulu sebelum melakukan pengambilan data. Berdasarkan perhitungan berikut diperoleh tinggi terbang yang harus dilakukan.

1. Lebar objek terkecil yang ingin dicapai sebesar $1 \mathrm{~cm}$.

2. Ukuran format CMOS yang digunakan $4,65 \mathrm{~mm} \times 6,20 \mathrm{~mm}$.

3. Panjang fokus kamera yang digunakan $3,61 \mathrm{~mm}$.

4. Jumlah piksel yang diambil $4000 \times 3000$ piksel

Atas dasar media yang digunakan tersebut, dihitung:

Memanjang $=6,20 \mathrm{~mm} \times 1000$ micron $/ 4000$ pixels $=1,5$ micron

Melintang $=4,65 \mathrm{~mm} \times 1000$ micron $/ 3000$ pixels $=1,5$ micron

Tinggi terbang $=10.000$ micron $/ 1,5 \mathrm{~mm}$ x 3,6 1mm / 1000

$$
=24 \text { meter }
$$

Dari perhitungan tersebut diperoleh tinggi terbang dilapangan $24 \mathrm{~m}$ di atas permukaan tanah (GSD $1 \mathrm{~cm}$ ). Resolusi Piksel ditanah atau Ground Sample Distance (GSD)didapat dari perhitungan dengan tinggi terbang pemotretan $24 \mathrm{~m}$. Dilapangan digunakan sistem auto pilot dengan setting ketinggian pada pilihan angka genap, yaitu 20 meter, sehingga GSD atau resolusi piksel foto didapat dibawah $1 \mathrm{~cm}$, yang dapat menentukan ketajaman gambar, sehingga objek pada badan jalan dapat dideteksi diatas foto udara. Foto yang didapat juga selain berosolusi tinggi memiliki tingkat akurasi multi point matchingyang cukup seragam, dengan multi image matching foto udara drone yang diambil secara bertampalan (LAP) baik pertampalan kedepan atau overlap maupun pertampalan kesamping atau sidelap. Pada Gambar 2 ditunjukkan bahwa foto 1 dan foto 2 saling bertampalan baik kedepan maupun kesamping sehingga bisa dilanjutkan untuk mendapatkan panjang exposure. 


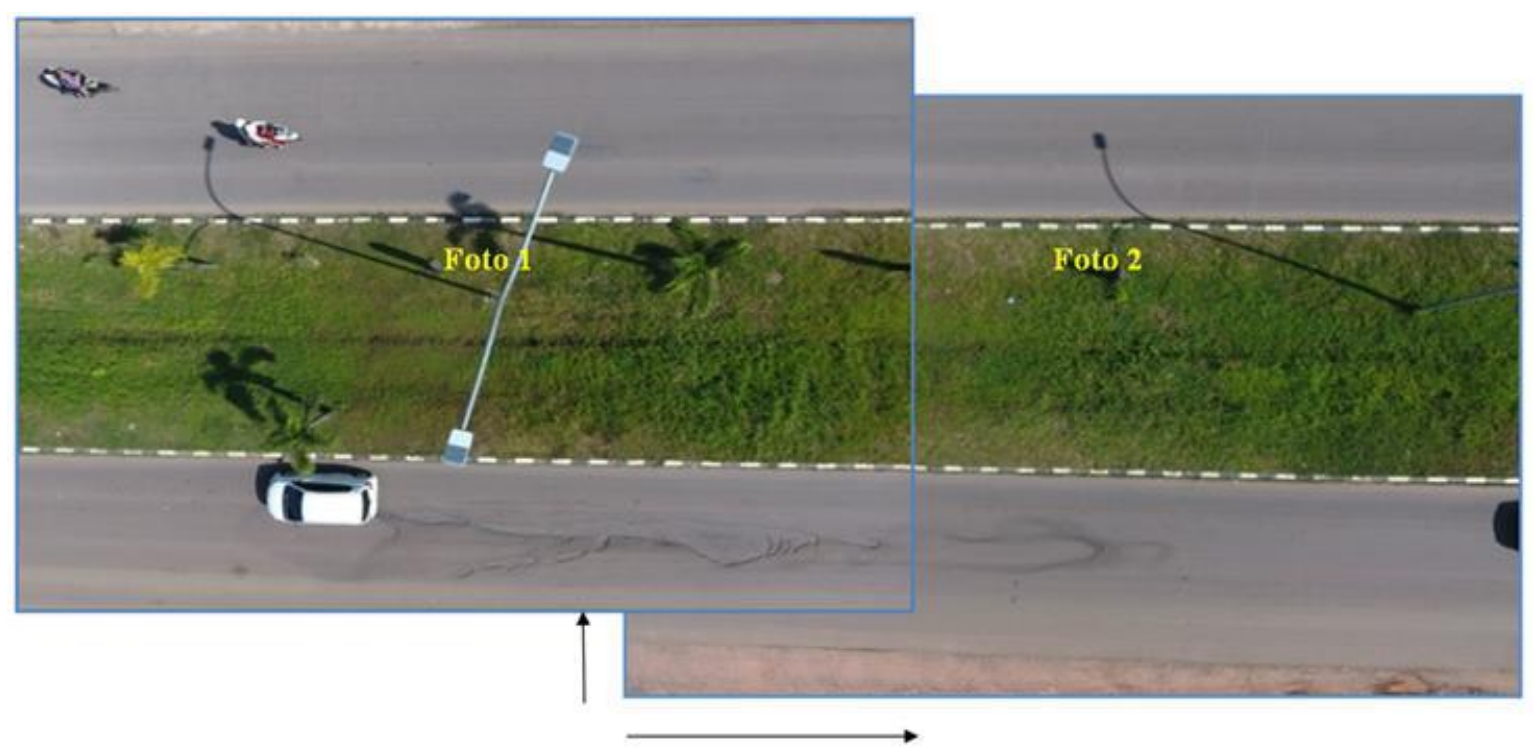

Gambar 3. Jarak Antar Exposure

Sumber: Decky et al, 2017

\section{Geotagging Foto Udara Drone}

Penentuan koordinat dilapangan dilakukan dengan menggunakan Geotagging sebagai proses foto udara pada sistem koordinat latitude, longitude, dan altitude foto udara drone. Proses geotagging ini menggunakan cara online, dengan setiap exposure foto secara otomatis mencatat koordinat Latitude, Longitude, dan altitudenya yang terlihat bila foto yang disorot diklik, sehingga muncul tabel metadata dengan format EXIF.

\section{Pengolahan Foto Udara Drone}

Pengolahan foto udara dilakukan dengan menggabungkan foto-foto dengan proyeksi mosaik. Beberapa perlu dilakukan dalam proses pengelolaan foto udara ini.

\section{Kaliberasi Foto}

Seluruh foto udara yang diunggah (upload) pada memori komputer harus dikaliberasi terlebih dahulu dengan teknik nadir sejajar. Foto yang miring tidak digunakan terutama pada ujung jalur terbang, sewaktu pesawat belok menuju jalur terbang selanjutnya dan tetap memotret, yang biasanya terletak pada posisi foto yang paling pinggir, seperti ditunjukkan oleh tanda lingkaran merah pada Gambar 4. Selanjutnya perangkat lunak akan memilih piksel yang matching untuk seluruh piksel foto yang diunggah pada RAM komputer. Proyeksi ini dimulai dengan identifikasi tie point pada foto udara hasil pemotretan secara otomatis. Pada proses ini juga dilakukan proses alignment, pemodelan geometri, dan pemodelan photo texture $3 D$. Kemudian dilakukan transformasi koordinat konform 3D dan ekspor ortofoto dan DEM. Semua proses tersebut dilakukan dengan menggunakan perangkat lunak Agisoft.

\section{Proses Alignment}

Proses alignment foto ini dilakukan pada tahap awal pengenalan objek permukaan badan jalan yang berada pada setiap piksel foto multipel agar menjadi satu objek, sehingga foto- 
foto tersebut tergabung menjadi satu layout foto yang besar. Identifikasi mengenai informasi utama pengolahan foto dihasilkan pada proses ini.

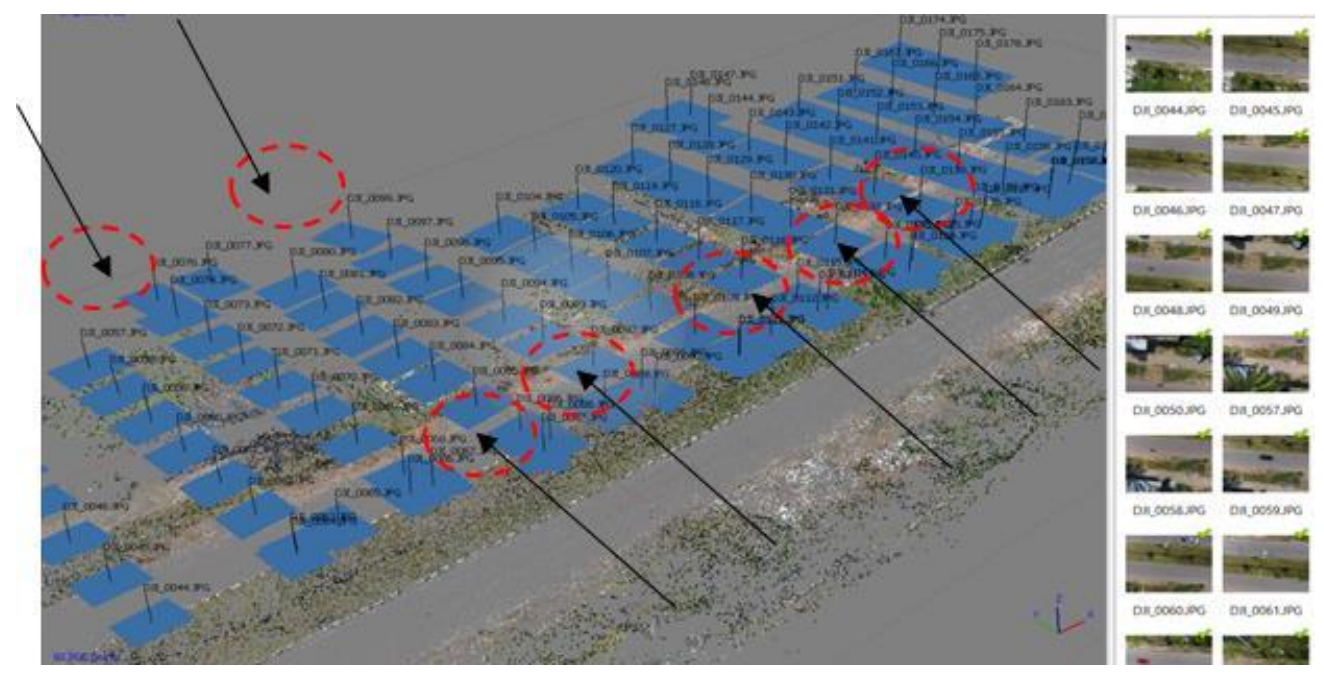

Gambar 4. Kaliberasi Foto dengan TeknikNadir Sejajar Sumber: Decky et al, 2017

Contoh hasil proses alignment dapat dilihat pada Gambar 5, yang merupakan hasil proses aligment di salah satu segmen Jalan H. M Noerdin Pandji menggunakan teknik chunk (selected area). Pada proses aligment ini setiap objek dipermukaan jalan muncul diberbagai format foto yang dilakukan secara berurutan. Objek-objek foto tersebut dikenali sedemikian rupa sehingga foto-foto yang kecil hasil pemotretan akan tergabung menjadi blok foto blok yang lebih besar,dan gambar objek yang muncul di beberapa foto hanya tampak pada satu gambar saja pada foto yang lebih besar.

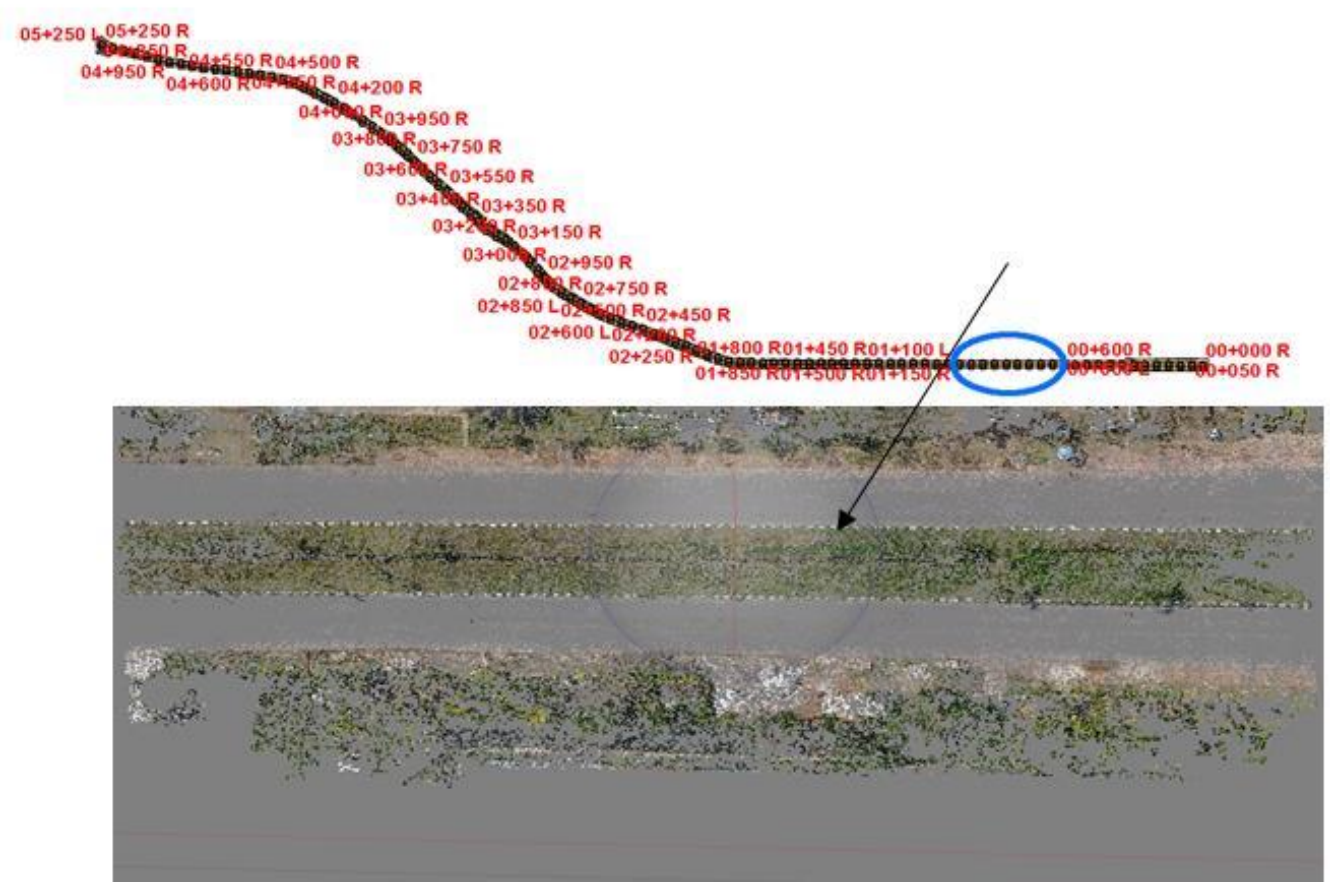

Gambar 5. Hasil Alignment Foto

Sumber: Decky et al, 2017 
Pada tahap ini dilakukan pendefinisian dan penampalan tie point secara otomatis melalui nilai kesamaan piksel pada image. Proses alignment menghasilkan gambar yang membentuk points cloud pada foto-foto yang memiliki hubungan pada overlap dan sidelap.

\section{Build Geometry}

Ukuran maupun bentuk yang didapat dari setiap piksel-piksel berdasarkan pada proses alignment foto yang diolah lagi sesuai dengan tahap awal dibentuknya DEM, untuk identifikasi secara visual pada proses geometry.Terlihat pada Gambar 6 bahwa setiap piksel pada format foto telah membentuk suatu badan jalan yang lurus dan adanya bangunan, seperti atap rumah, sesuai objek pada foto yang telah dimodelkan dengan syarat geometri tetapi masih tampak rata dan belum begitu jelas teksturnya dan sekilas sudah menyatu, walaupun masih keliatan ada yang belum tertutup bila gambar tersebut dibesarkan.

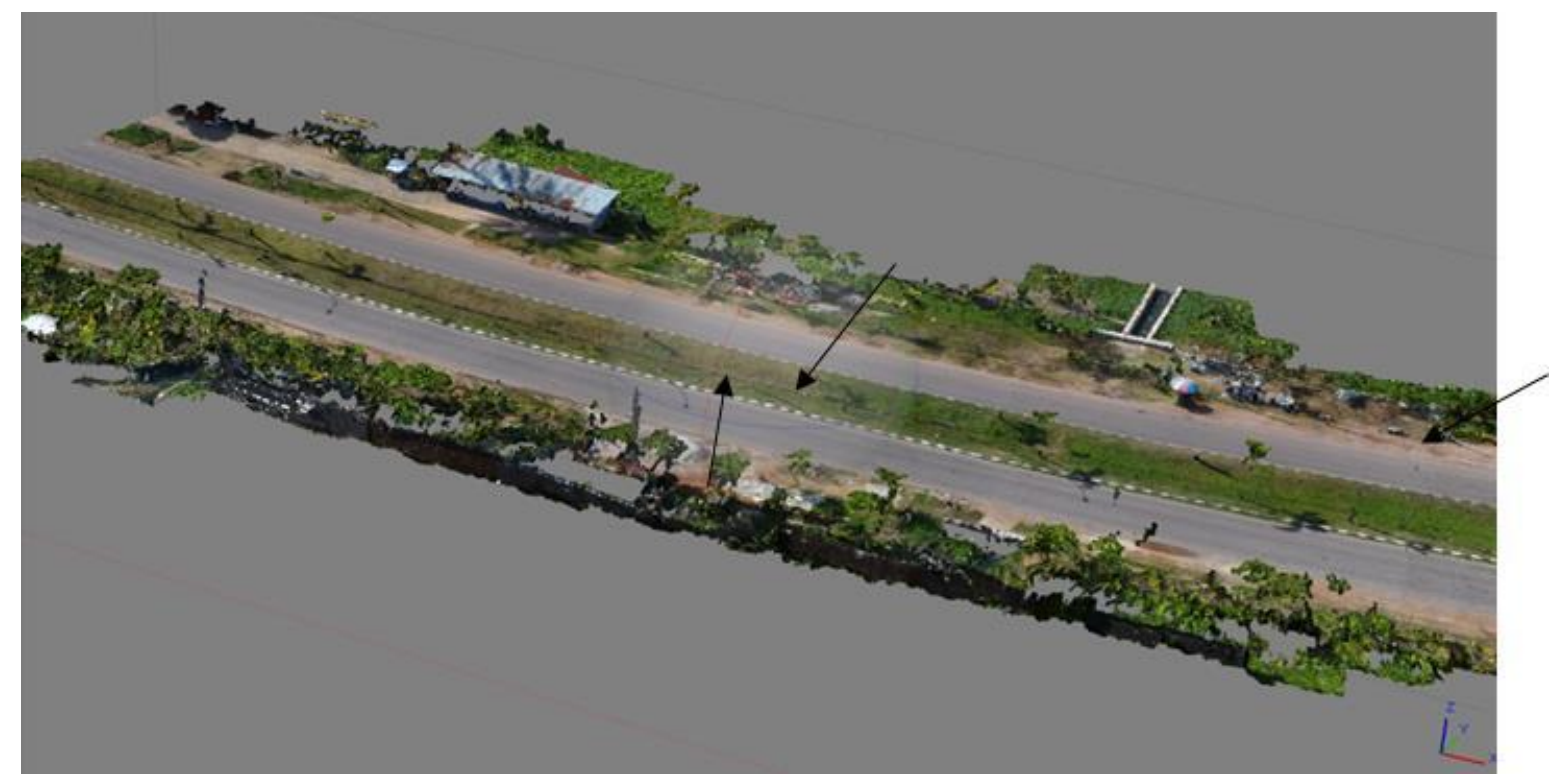

Gambar 6. Tampilan pemodelan geometri Sumber: Decky et al, 2017

\section{Hasil Orthofoto}

Selanjutnya dibentuk mosaik foto yang merupakan hasil penggabungan foto-foto kecil, setelah tahap pengenalan alignment yang sudah terkoreksi ukuran geometrinya, dengan terlihat adanya jalan, median jalan dan vegetasi, termasuk lampu jalan dan bayangannya. Semakin besar jumlah piksel, semakin kecilatau semakin rapat ukuran 1 piksel. Dengan banyaknya jumlah piksel, semakin banyak memori yang digunakan untuk menyimpan project. Sambungan mosaik yang dihasilkanpun sangat jelas terlihat, dan jika dilakukan pembesaran gambar untuk beberapa kali juga tidak menyebabkan gambar pecah

\section{KESIMPULAN DAN SARAN}

Dari penelitian ini dapat ditarik kesimpulan sebagai berikut: 
1. Perilaku korban kecelakaan yang terinci di suatu ruas jalan dan pengguna sepeda motor tanpa menggunakan helm dapat direkam dengan kamera drone yang diterbangkan pada ketinggian tertentu.

2. Selain menghasilkan gambar, metode pendataan menggunakan drone menghasilkan perilaku kecelakaanlalu lntas menurut jenis, kelas, fungsi,dan geometrik jalan.

Selain itu dapat diberikan saran sebagai berikut:

1. Penelitian selanjutnya ini perlu dilaksanakan dengan menggunakan drone yang dilengkapi dengan kamera dan penggunaan perangkat lunak untuk merekonstruksi dan mendokumentasikan kecelakaan dengan perolehan dataphotogrammetricsecara cepat (dalam beberapa menit).

2. Pemilihan alat drone sebaiknya yang terkait dengan ilmu geodesi, sehingga koordinat dan level yang diperoleh dapat dimanfaatkan untuk menggambarkan posisi geometrik jalan tempat terjadinya kecelakaan lalu lintas.

\section{UCAPAN TERIMA KASIH}

Ucapan terima kasih disampaikan kepada KORLANTAS POLRI yang telah mengijinkan penggunaan data IRSMS untuk penelitian ini, serta bantuan Hibah Traffic Accident Research Center (TARC) tahun 2018 dalam terselenggaranya kegiatan penelitian ini.

\section{DAFTAR PUSTAKA}

Erika Buchari, 2014, The Importance Of Variable Data Of Traffic Accident In Palembang City, Proceedings of SIBE Conference, ITB, Bandung.

Booysen et al, 2015, Drone-based Traffic Flow Estimation and Tracking Using Computer

Vision, Proceedings of Conference, South African Transport Conference, At Pretoria, DOI: 10.13140/RG.2.1.1024.6888.

ISLAM et al, 2015, Identification of Factors in Road Accidents through in Depth Accident Analysis, http://doi.org/10.1016/SO386.1112 (14) 60209-0

Decky et al, 2017, Road Damage Data Collection Method By Using PhotoSmall Format Recorded by Drone, Proceeding of Ico-Ascnitec, 2017, ISSN 25982532. 